\title{
Tables, Figures, Plates
}

\section{Tables}

1.1 Top 10 costliest world earthquakes and tsunamis by insured losses, 1980-2001

1.2 Major focus of chapters in relation to stages of disaster management cycle

2.1 Socioeconomic characteristics of respondents

2.2 Provisional timeframes of a fault earthquake in the Etna area

2.3 Level of threat due to earthquake

2.4 Earthquake risk: Sources of information 44

2.5 Community preparedness initiatives

2.6 Respondent perception of preparedness with respect to a seismic event

2.7 Perceptions of community belonging

2.8 Preparation acts for business resilience

4.1 Number of foreign visitors to Indonesia and Bali, 1969-2018

4.2 Number of rooms in classified hotels, non-classified hotels and other accommodation in the southern coastal region of Bali

7.1 Kumamoto Earthquake (earthquakes recorded stronger than M 5.0) between 14 April and 31 August 2016

7.2 Earthquake frequency by magnitudes (14 April 2016-30 June 2017)

8.1 Core business of respondents

8.2 The recovery period of business entities after the Jogjakarta Earthquake

$\begin{array}{lll}10.1 & \text { Ghost tourism cities } & 174\end{array}$

10.2 Research participants: Local community members 179

$\begin{array}{lll}10.3 & \text { Research participants: Tourists } & 179\end{array}$ 
viii Tables, Figures, Plates

\section{Figures}

1.1 System dimensions of tourism in earthquake affected destinations $\quad 11$

2.1 Fault earthquake risk: Perception of preparedness 43

2.2 Discussion on earthquake preparedness 47

2.3 Opinion regarding consequences of fault earthquake 47

2.4 Opinion regarding consequences of fault earthquake 48

7.1 Kumamoto Earthquake epicentres and surrounding area 116

8.1 The most widely perceived business difficulties after the earthquake

\section{Plates}

4.1 Hotel displaying tsunami evacuation signage at

Sanur Beach, 2017

4.2 Temporary Tsunami Evacuation Centre in Serangan Village

7.1 Aso Farmland accommodation poster at the entrance to Aso Farmland complex 